\title{
A framework for planning green spaces in rural South Africa
}

\section{Elizelle Juaneé Cilliers}

Unit for Environmental Sciences and Management, North-West University, Potchefstroom Campus, South Africa, 2520

\author{
Email address: \\ juanee.cilliers@nwu.ac.za
}

\section{To cite this article:}

Elizelle Juaneé Cilliers. A Framework for Planning Green Spaces in Rural South Africa. Agriculture, Forestry and Fisheries. Special Issue: Planning for Sustainable Communities: Green-Spaces in Rural Areas. Vol. 4, No. 4-1, 2015, pp. 80-86. doi: 10.11648/j.aff.s.2015040401.20

\begin{abstract}
The importance of planning for green spaces is well captured in literature, focusing on the direct and indirect benefits which such spaces provides to various beneficiaries, from local authorities to local communities. However, the planning and implementation of such spaces, especially in a rural context, is complex. The value of spaces is perceived differently by different stakeholders, and this is also true for the rural environments, characterized with unique challenges and needs. This paper captures the value of green spaces and relates it to specific rural considerations, in order to state the value that green spaces can provide to rural areas and communities. The Vaalharts case study is used to explain current realities and best practice options and the paper concludes with a framework for the planning of green spaces in rural South Africa, including all aspects and design elements that should be considered in the planning and provision of green spaces.
\end{abstract}

Keywords: Green spaces, rural areas, framework, Vaalharts rural area

\section{Planning for Green Spaces}

\subsection{Understanding Green Space}

A public green space is defined as every parcel of land classified as a natural surface, judged to be publicly accessible [1]. 'Natural surface' implies predominantly natural area with a sense of quality and the presence of several maintained facilities [2]. Green space includes public and private open spaces in urban and rural areas, primarily covered by vegetation. Public green spaces include parks, forests, golf courses, sports fields and other open nature areas and are seen as the key approach in areas where residential plot sizes are inadequate (as in the case of most rural areas), or the housing stock is dominated by multi-storey buildings [3] in high density urban areas. Qualitative green space, as referred to in this research, include green spaces that provide a specific function to communities, ranging from social, ecological, economic, psychological, health and amenity functions [4], [5].

\subsection{Approaches to Planning Green Spaces}

There is currently an expanded scientific understanding that green spaces are substantially beneficial to urban and rural communities [6]. An important concept regarding the understanding and conceptualizing of green spaces is their influence on and contribution to shifting the paradigm of spatial segregation of urban landscape functions into complete multifunctional landscapes [2] wherein 'quality' regarding these spaces are linked to the 'value' associated with spaces by recognizing the need of these spaces to reflect the changing social, economic and environmental conditions. Research captured in this journal contributes to the importance of driving the green-agenda and identified various benefits of green spaces in terms of social, economic and environmental benefits, in order to emphasize the importance of such spaces and the necessity to plan and provide green spaces.

\subsection{Complexity of Planning for Rural Areas}

Rural communities and the development thereof continue to be one of the main priorities within frameworks and constitutions guiding the economic and social development of (especially developing) countries [7]. In South Africa, rural development is an predominant challenge as it is estimated that half of South Africa's population lives in rural areas [8] and that three quarters of the people living below the MLL (minimum living level) live in these rural areas [9].

Planning for rural areas is complex as rural areas have unique challenges and characteristics to take into consideration, such as location challenges (geographic disparities), dispersed rural settlement structures, lack of 
integrative policies, sociological issues (crime and violence, poor education, lack of facilities), economic issues (declining per capital income, mass unemployment), lack of community participation, level of education, ability to communicate, social issues (provision of basic services, limited access to health care, standard of health, level of poverty), and environmental issues (lack of clean water and lack of qualitative green spaces) [10], [8], [11], [12], [13], [7], [14], [15].

Furthermore, the current planning approach is often project oriented and seldom supports green growth and green space planning [16]. The need for an inclusive approach which considers community participation and stakeholder engagement, whilst considering the wide scale of impact related to green space planning should be recognised, and implemented.

\section{Valuing Green Spaces}

Green spaces are complex to valuate as the market for environmental quality does not yield an observable unit price. The value of green spaces needs to be identified in order to emphasize the importance of planning for such spaces. The value of green spaces can be divided in two categories, namely indirect benefits and direct benefits, as captured in the following table.

Table 1. Identifying the benefits of green space provision

\begin{tabular}{|c|c|c|c|}
\hline \multicolumn{2}{|c|}{ Benefits } & \multirow{2}{*}{$\begin{array}{l}\text { Measurable } \\
\text { Ecosystem services }\end{array}$} & \multirow{2}{*}{$\begin{array}{l}\text { Source } \\
{[17]}\end{array}$} \\
\hline \multirow{22}{*}{ 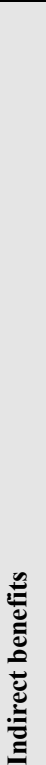 } & \multirow{10}{*}{ 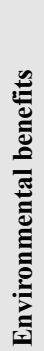 } & & \\
\hline & & Enhanced biodiversity & [18] \\
\hline & & Storm water management & {$[17]$} \\
\hline & & Habitat provision & [19] \\
\hline & & Reduced carbon dioxide & [20] \\
\hline & & Improved air quality & [21] \\
\hline & & Reduced pollution & [22] \\
\hline & & Microclimate and heat island effect & {$[23],[24]$} \\
\hline & & Noise reduction & {$[22]$} \\
\hline & & Sustainability & {$[25]$} \\
\hline & \multirow{12}{*}{ 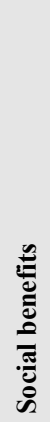 } & Leisure and recreation & [26] \\
\hline & & Social contact, access to experience & {$[27],[28]$} \\
\hline & & Physical and psychological health & [29], [30] \\
\hline & & Aesthetic value & [31] \\
\hline & & Quality living space & [32] \\
\hline & & Positive perceptions & [33], [19] \\
\hline & & Community cohesion & {$[27],[28]$} \\
\hline & & Levels of physical activity & {$[21],[34]$} \\
\hline & & Reduced stress, increase happiness & {$[35],[36]$} \\
\hline & & Positive impact on children & {$[37]$} \\
\hline & & Lower levels of fear & [29] \\
\hline & & Better neighbourhood relationships & [19] \\
\hline \multirow{9}{*}{ 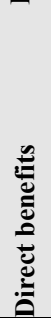 } & \multirow{9}{*}{ 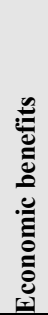 } & Favourable image of place & {$[38]$} \\
\hline & & Boost retail sales and tourism & [38] \\
\hline & & Inward investment in area & [39] \\
\hline & & Encouraged employment & [19] \\
\hline & & Property values & {$[40],[41]$} \\
\hline & & Neighbourhood value & {$[42],[43]$} \\
\hline & & House buyers preferences & {$[44],[45]$} \\
\hline & & Positive influence in crime areas & [46] \\
\hline & & Development impact on children & [46] \\
\hline
\end{tabular}

These benefits will be explained accordingly.

\section{Indirect Benefit of Green Spaces: Social Value}

\subsection{Local rural Reality and Social Challenges}

The issue of safety and security is identified as a precondition for social and economic development in South Africa [14], [9]. Perceptions regarding safety can differ according to several factors found within an environment, including employment status, population, group and area of residences [47]. Therefore it can be inferred that rural communities may be prone to incidents of crime and safety issues as they typically fall under the category of low employment and are situated in areas with low accessibility and environmental quality [7].

Bad perceptions regarding safety and security within a neighbourhood result in other social challenges as communities avoid open spaces and are thereby excluded from recreational possibilities, social interaction, and other benefits that such open spaces provide. With a third of households in rural areas in South Africa avoiding these open spaces, social interaction and growing social cohesion continue to falter [47].

\subsection{Green spaces Addressing Social Challenges}

Any public space can be contributory to the insecurity of an area if it becomes a place of relegation, neglect, degradation and/or illegible which allures a range of uncivil acts, delinquency and vulnerability [48]. The importance of providing qualitative green spaces within rural areas can enhance social development and address social issues. By creating public green spaces which are fully maintained and cared for, the feeling of being unsafe is eliminated, contributing to the overall value and success of these public green spaces [2].

The priority within rural areas is usually focused on providing basic services, facilities and infrastructure, and the provision of qualitative open spaces is often neglected [49]. Apart from the abovementioned social benefits that green spaces provide to (especially rural) areas, numerous of literature confirms that outdoor play spaces are vital for children's learning and developing stages throughout life [50], [49], [51], [52].

\section{Indirect Benefits of Green Spaces: Environmental Value}

\subsection{Local reality and Environmental Challenges}

Green spaces play various roles in creating sustainable urban and rural areas [53]. Green spaces are fundamental areas in human settlements that need intentional planning as it provides the opportunity to enhance sustainability and the appearance of environmental benefits [39]. 


\subsection{Addressing Environmental Challenges in Rural Areas Through Green Spaces}

Land use change and environmental quality are closely related, and the nature and location of development can significantly influence both the generation and resolution of environmental problems. Green spaces (linked to ecosystem services) provide various services, such as (1) provisioning services, including food production, medicinal resources, (2) regulating services, including climate and air quality regulation, carbon sequestration and storage, waste-water treatment, erosion prevention, maintenance, of soil fertility, biological control, (3) supporting services, including habitats for species, maintenance of genetic diversity, (4) cultural services, including recreational and mental health, tourism, aesthetic appreciation, sense of place and experience of place [54], [55].

The planning and provision of green spaces should thus consider environmental sustainability and the green space system should be developed with the aim of establishing a network of natural features and compatible land uses that will act as a green network [56].

\section{Direct Benefits of Green Spaces: Economic Value}

\subsection{Local reality and Economic Dimension of Planning}

The importance of green spaces were known for decades; however, the relationship between liveability and green spaces as incorporated in overall spatial planning approaches has become the focus of international studies [57]. Often spatial planning decisions are based on pro-developmental approaches, linked to the revenue or economic benefit as a direct result from the development [55]. The understanding that green spaces can contribute to the economic value of an area or development, is not yet fully integrated in spatial planning approaches.

\subsection{Green space Provision Addressing Economic Challenges in Rural Areas}

Research regarding the economic value of green spaces confirms that most people are willing to pay more for a residential property close to a green space, emphasizing the positive impact on residential property values. Research further proved that green spaces create a favourable image for a place, boost retail sales, attract tourism [38], enhance inward investment in the area [39], and encourage employment (emphasizing the impact on production values).

Rural areas are often neglected in terms of green space provision, and this might be directly linked to the lack of qualitative public spaces, lack of economic opportunities, lack of investment opportunities and lack of other economic spinoffs that were proven to be true when providing green spaces within neighborhoods.

\section{Quantifying the Value of Green Spaces}

The value of green spaces needs to be identified (as captured in previous sections in terms of social value, economic value and environmental value) in order to emphasize the importance of planning for green spaces. But, the value of green spaces should also be quantified (measurable) in order to have more weight in the decision-making processes [40], and survive against the susceptibility to urban pressures [50].

The green space values, as stated, are divided in indirect benefits and direct benefits. Indirect benefits are hard to quantify in monetary terms and include social aspects and environmental aspects. Direct benefits refer to the direct economic benefit as a result of the provision of green spaces within an area, and are more easily translated into monetary terms and financial gains.

Literature identifies four main approaches to determine the economic value green-spaces in terms of: (1) the economic approach, (2) the development approach, (3) the ethical or moral approach and (4) the utilitarian approach [4], [58], [40]. [59], [60], [61]. The scope of this paper is not to review these different methods but to identify the different values of green spaces and propose that these values be quantified as part of formal spatial planning processes.

In the process of quantifying values of green spaces, the beneficiaries of the green values should be identified, as green spaces have different value for different beneficiaries. In this sense, green spaces provide different values to communities, in comparison to the values it provide to local authorities. These beneficiaries and related values are captured in the following table.

Table 2. Beneficiaries and values of green spaces

\begin{tabular}{|c|c|c|}
\hline & Local authority benefit & Local community benefit \\
\hline 焉 & $\begin{array}{l}\text { More citizen participation } \\
\text { Voluntary contribution } \\
\text { Social capital } \\
\text { Aesthetic spaces } \\
\text { Maintenance of green space } \\
\text { Higher biodiversity } \\
\text { Sustained eco-systems } \\
\text { Sustainable spaces } \\
\text { Emission removal } \\
\text { Green proximity tax } \\
\text { Energy savings } \\
\text { Higher market values } \\
\text { Storm water mitigation }\end{array}$ & $\begin{array}{l}\text { Accessibility to green spaces } \\
\text { Cultural benefits } \\
\text { Better living spaces } \\
\text { Health benefits } \\
\text { Availability of green spaces } \\
\text { Aesthetic area } \\
\text { Recreational spaces } \\
\text { Quality of life } \\
\text { Better working spaces } \\
\text { Inward investment } \\
\text { Higher property prices }\end{array}$ \\
\hline
\end{tabular}

\section{Implementation: Vaalharts Case Study}

Vaalharts is a rural area located in the greater Polokwane municipality district, in the North West and Northern Cape provinces of South Africa. The Vaalharts area claims the second largest irrigation scheme in the Southern Hemisphere namely the Vaalharts Irrigation Scheme [62]. Accordingly the environmental, social and economic issues present in this area will be captured. 


\subsection{Current Reality and Environmental Issues in Vaalharts}

The environment is characterized by natural green areas, agricultural areas, rural residential settlements and nature reserves. There are mostly natural indigenous plants and agricultural vegetation present in the area. The area is highly accessible and residents are dependent on the environment for provisioning, regulating, supporting and cultural services. The abundance of water (due to the Vaalharts Irrigation Scheme) enhances the potential and provision of sustainable green spaces, and the Vaalharts area has the potential to support the needed ecosystem services.

However, green spaces in this area are mostly left unplanned with no vision, usage or maintenance plans. Green spaces are isolated from each other and most open spaces are homogeneous (similar in appearance as well as function). A lack of finances for the planning of green spaces is part of the current reality, along with a lack of knowledge on environmental benefits amongst communities and authorities.'

\subsection{Social issues identified in Vaalharts}

The social composition of residents is characterised by rural communities with limited education, training or opportunities to social and economic development. A conclusive need-assessment was conducted [62] based on data obtained from a sample of 31 willing individuals and a stratified sample of 958 randomly drawn participants in order to identify social issues and needs [7]. The research identified social challenges in terms of lack of basic government services, lack of educational related services, agricultural challenges, lack of community facilities, health and welfare challenges, safety and security issues and lack of emergency services [62].

Community members identified core actions to address these social problems [62], as (1) provision of recreation facilities, (2) enhancing sports, arts and culture and youth activities in the communities and (3) providing help and support for people with disabilities, the elderly and people who are terminally ill.

\subsection{Economic Issues Identified in Vaalharts}

Characterized as a rural area, there are limited economic opportunities in the Vaalharts area. The need-assessment identified the lack of employment and lack of adequate facilities as core economic issues to be addressed [62]. The Vaalharts Irrigation Scheme is probably the sole initiator of economic potential in the area. The area is in need of an integrated development approach to guide future planning. The consideration of the economic value that green spaces can provide to this area need to form part of such an integrated approach.

\subsection{Green space Provision Addressing Identified Issues}

Based on the literature investigation presented in this research, green spaces can contribute and address (some) of the identified issues of the Vaalharts area.
The planning and provision of qualitative green spaces in this area should be directly linked to the Vaalharts Irrigation Scheme and access to water, enabling the provision of sustainable green spaces and ecosystem services. An integrated plan, driving the green agenda, should link current isolated spaces and provide a future vision and management plan, for different typologies of green spaces. Authorities and communities needs to be informed about the benefits of green spaces in order to ensure the success of such spaces. Providing qualitative green spaces ensures adequate community engagement possibilities and the strengthening of social cohesion. It provides recreational opportunities that will reflect in health and welfare benefits. Qualitative green spaces can be directly beneficial for child-development as it relates to the planning of child-friendly spaces. The provision of qualitative green spaces will enhance the identity of the area and increase inward investment in the area. This will result in further economic spinoffs. Accordingly an integrated framework for the planning and development of green spaces in rural areas will be presented, based on the theoretical investigations, international best practice approaches and findings in terms of the local reality and rural challenges.

\section{Conclusions: Integrated Framework for Planning Green Spaces}

An integrated framework to guide local planning approaches, focusing on environmental benefits, social benefits and economic benefits of green spaces should be inclusive of the following aspects:

\subsection{Identifying the value of green spaces}

The value of space is subjective and should be identified within the local context, considering the unique challenges and opportunities present in the specific area. The following aspects need to be considered as point of departure when planning green spaces:

Table 3. Aspects to consider as point of departure

\begin{tabular}{|c|c|}
\hline Aspects to consider & Description \\
\hline Typology of green spaces & $\begin{array}{l}\text { Identify different types of green spaces } \\
\text { for possible implementation }\end{array}$ \\
\hline African considerations & $\begin{array}{l}\text { Consider unique challenges and cultural } \\
\text { needs }\end{array}$ \\
\hline Policies and legislation & Refer to guiding legal requirements \\
\hline Participatory planning & $\begin{array}{l}\text { Include the community in the formal } \\
\text { planning process }\end{array}$ \\
\hline Place-making elements & $\begin{array}{l}\text { Consider elements that will enhance } \\
\text { identity of place and contribute to value } \\
\text { of the space }\end{array}$ \\
\hline Layout and design & $\begin{array}{l}\text { Consider natural restrictions and } \\
\text { opportunities present in the area }\end{array}$ \\
\hline
\end{tabular}

\subsection{Identifying methods and beneficiaries of green spaces}

The different methods to value green spaces, along with the identification of the beneficiaries of the planed green space should be determined accordingly. 
The chosen method to value green spaces should fit the local context and environment. The economic approach and development approach should be used in areas where residential values are known and related to market values. This is, for example, not possible in rural areas where subsidy housing, backyard rentals and informal housing provision are predominant. The ethical approach or utilitarian approach would thus be a better method to utilize in rural areas, subject to availability of data and resources.

In the same sense, beneficiaries should be identified for each space and area. The added value as a result of the planning and provision of green spaces should be known to the different beneficiaries in order to enhance social capital and the buy-in from these stakeholders.

\subsection{Quantifying the Value of Green Spaces}

The value of green spaces should, as final output, be quantified in order to emphasize the value of these spaces and have more weight in the decision-making process. The following issues and design elements need to be considered in the valuing of current green spaces and planning of future qualitative green spaces. A multi-criteria analysis can be used to quantify these issues.

1. Indirect benefits:

a. Social values

- Identity of place

- Attractions provided

- Flexibility

- Seasonal opportunities

- Accessibility

- Visibility

- Lighting

- Landscaping

- Signage

- Access control

- Proximity to nodes

- Safety considerations

- Maintenance

- Recreation possibilities

- Social contact

- Physical and mental health

- Aesthetic value

- Quality living space

- Positive perceptions

- Community cohesion

- Levels of physical activity

- Reduced stress levels

- Increased happiness

- Social cohesion

b. Environmental values

- Ecosystem services

- Biodiversity

- Storm water management

- Habitat provision

- Environmental quality

- Reduced pollution

- Microclimate regulation
- Noise reduction

- Enhanced sustainability

- Linked spaces

- Integrative approach

c. Child-friendly spaces

- Safety

- Natural setting

- Access

- Sociability

- Integration

- Located near schools

- Walkable distances

- Transportation options

- Adequate surfaces and edges

- Public furniture

- Amenities,

- Safe and visible entrances

- Appropriate signage

- Development opportunities

- Participatory planning

- Multi-disciplinary approach

2. Direct benefits

d. Economic values

- Image of place

- Increased retail sales

- Increased tourism

- Inward investment in area

- Encouraged employment

- Higher property values

- Increased neighborhood value

- Positive influence in crime areas

\section{Acknowledgements}

This research (or parts thereof) was made possible by the financial contribution of the NRF (National Research Foundation) South Africa. Any opinion, findings and conclusions or recommendations expressed in this material are those of the author(s) and therefore the NRF does not accept any liability in regard thereto.

\section{References}

[1] O. Barbosa, J.A. Tratalos, P.R. Armsworth, R.G. Davies, R.A. Fuller, P. Johnson and K.J. Gaston, "Who benefits from access to green space? A case study from Sheffield, UK", Landscape and Urban Planning, vol. 83, pp. 187-195, 2007.

[2] C.M. Shackleton and A. Blair, "Perceptions and use of public green space is influenced by its relative abundance in two small towns in South Africa", Landscape and urban Planning, vol. 113, pp. 104-112, 2013.

[3] M.M. McConnachie and C.M. Shackleton, "Public green space inequality in small towns in South Africa," Habitat International, vol. 34(2), pp. 244-248, 2010.

[4] C.M. Sutton, on urban open space: a case study of Msunduzi Municipality, South Africa. Canada: Queens University. (Thesis - B.Sc). School of Environmental Studies. 139 p, 2006. 
[5] E. Lange, S. Hehl-Lange and M.J. Brewer, "Scenario-visualization for the assessment of perceived green space qualities at the urban-rural fringe", Journal of Environmental Management, vol. 89, pp. 245-256, 2007.

[6] K.L. Wolf, on public value of nature: economics of Urban trees, parks and open space, Design with Spirit, Washington: Edmond, uEnvironmental Design Research Association, 2004.

[7] N. De Jong, Addressing social issues in rural communities by planning for lively places and green spaces, Dissertation submitted to the North-West University, Potchefstroom, 2013.

[8] Campbell, C., Nair, Y., Maimane, S. \& Sibiya, Z. 2008. Supporting people with AIDS and their carers in rural South Africa: Possibilities and challenges. http://eprints.lse.ac.uk/5471/ Date of access: 28 Feb. 2013.

[9] Department of Rural Development and Land Reform, Rural Development Framework, Pretoria, South Africa, 1997.

[10] Gopaul, M. 2006. The significance of rural areas in South Africa for tourism development through community participation with special reference to Umgababa, a rural area located in the province of KwaZulu-Natal. Pretoria: University of South Africa. (Dissertation - Master of Arts).

[11] Van der Ploeg, H. Renting, G. Brunori, K. Knickel, J. Mannion, T. Marsden, K. de Roest, E. Sevilla-Guzman, E. and F. Ventura, "Rural Development: From Practices and Policies towards Theory," Sociologis Ruralis, vol. 40(4), pp. 391-408., 2000.

[12] L. Lategan, A study of the current South African housing environment with specific reference to possible alternative approaches to improve living conditions, Masters dissertation submitted to the North-West University, South Africa, 2012.

[13] South Africa, Department of Housing, White Paper on a New Housing Policy and Strategy for South Africa, 1994/

[14] Department of Rural Development and Land Reform, Integrated Sustainable Rural Development Strategy (ISRDS), Pretoria, South Africa, 2000.

[15] T. Cannon, J. Twigg and J. Rowell, Social vulnerability, sustainable livelihoods and disasters, Chatham, UK: Natural Resources Institute, University of Greenwhich, 2005.

[16] D.C. Okeke, An analysis of spatial development paradigm for enhancing regional integration within national and its supporting spatial systems in Africa, Doctoral Degree submitted to the North-West University, Potchefstroom, 2014.

[17] R. Stiles, "Urban spaces - enhancing the attractiveness and quality of the urban environment," WP3 Joint Strategy. University of Technology, Vienna, December 2006.

[18] S.S. Cilliers, E.J. Cilliers, C.E. Lubbe, S.J. Siebert, "Ecosystem services of urban green spaces in African countries-perspectives and challenges," Urban Ecosystems, vol. 16(4), pp. 681-702, 2013.

[19] E.J. Cilliers, E. Diemont, D.J. Stobbelaar and W. Timmermans, "Sustainable Green Urban Planning: The Workbench Spatial Quality Method," Journal of Place Management and Development, vol. 4(2), pp. 214-224, 2012.

[20] E.G. McPherson, S.E. Maco, J.R. Simpson, P.J. Peper, Q. Xiao, A.M. Van Der Zanden and N. Bell, on Western Washington and Oregon community tree guide: benefits, costs, and strategic planning. Silverton: International Society of Arboriculture, 2002.
[21] Greenspace Scotland, "Greenspace and quality of life: a critical literature review," Scotland, 2008, Http://www.openspace.eca.ac.uk/pdf/greenspace_and_quality of life_literature_review_aug2008.pdf Date of Access: 2 Apriil 2014.

[22] P. Bolund and S. Hunhammar, "Ecosystem services in urban areas," Ecological Economics, vol. 29(2), pp.293-301, 1999.

[23] H. Akbari, M. Pomerantz, and H. Taha, "Cool surfaces and shade trees to reduce energy use and improve air quality in urban areas," Solar Energy, vol. 70(3), pp. 295-310, 2001.

[24] E. Alexandri and P. Jones, "Temperature decreases in an urban canyon due to green walls and green roofs in diverse climates," Building and Environment, vol. 43(4), pp. 480-493, 2008.

[25] S. Hodgkison and JM. Hero, "The efficacy of small-scale conservation efforts, as assessed on Australian golf courses." Biological Conservation, vol. 135(4), pp. 576-586, 2007.

[26] E.J. Cilliers and W. Timmermans, "The importance of creative participatory planning in the public place-making process," Environment and Planning B: Planning and Design, vol 41. (EPB 139-098), 2014.

[27] A.E. Kazmierczak and P. James, on the role of urban green spaces in improving social inclusion, Salford: University of Salford, School of Environment and Life Sciences, 2008.

[28] F.E. Kuo, "The role of arboriculture in a healthy social ecology," Journal of Arboriculture, vol. 29(3), pp. 148-155, 2003.

[29] A, Van den Berg, T. Hartig, and H. Staats, "Preference for Nature in Urbanized Societies: Stress, Restoration, and the Pursuit of Sustainability," Journal of Social Issues, vol. 63(1), pp. 79-96, 2007.

[30] S.U. Roger, on health benefits of gardens in hospitals: Plants for People, Texas: Centre for health systems and design, 2003.

[31] B. Thaiutsa, L. Puangchit, R. Kjelgren and W. Arunpraparut, "Urban green space, street tree and heritage large tree assessment in Bangkok, Thailand," Forestry and Urban Greening, vol. 7(3), pp. 219-229, 2008.

[32] E.J. Cilliers, E. Diemont, D.J. Stobbelaar and W. Timmermans, "Sustainable Green Urban Planning: The Green Credit Tool," Journal of Place Management and Development, vol. 3(1), pp. 57-66, 2010.

[33] A. Chiesura, "The role of urban parks for the sustainable city," Landscape and Urban Planning, vol. 68, pp. 129-138, 2004.

[34] D.A. Cohen, J.S. Ashwood, M.M. Scott, A. Overton, K.R. Evenson, L.K. Staten, D.Porter, T.L. Mckenzie, and D. Catellier, "Public parks and physical activity among adolescent girls," Pediatrics, vol. 118, pp. E1381-E1389, 2006

[35] N. Owen, N. Humpel, E. Leslie, A. Bauman, and J.F. Sallis, "Understanding environmental influences on walking: Review and research agenda," American Journal of Preventive Medicine, vol. 27, pp. 67-76, 2004.

[36] R. Hansmann, S.M. Hug and K. Seeland, K, "Restoration and stress relief through physical activities in forests and parks," Urban Forestry \& Urban Greening, vol. 6, pp. 213-225, 2007.

[37] A.F. Taylor, F.E. Kuo and W.C. Sullivan, "Views of nature and self-discipline: Evidence from inner city children," Journal of Environmental Psychology, vol. 22, pp. 49-63, 2002. 
[38] H. Woolley, C. Swanwick and N. Dunnet, on nature, role and value of green space in towns and cities: an overview. 2003. www.atypom-link.com/ALEX/doi/abs/10.2148/benv.29.2.94. 54467.

[39] Cabe Space, "Paying for parks: Eight models for funding urban green space," London, 2005. www.cabe.org.uk/files/Paying-for-parks-full-report.pdf. (Accessed 20 April 2009).

[40] J. Luttik, "The value of trees, water and open space as reflected by house prices in the Netherlands," Landscape and Urban Planning, vol. 48, pp. 161-167, 2000.

[41] M. Lutzenhisher and N.A. Netusil, "Effect of Open Spaces on a Home's Sale Price," Contemporary Economic Policy, vol. 19, pp. 291-298, 2001.

[42] V.K. Smith, C. Poulos and H. Kim, "Treating open space as an urban amenity," Resource and Energy Economics, vol. 24, pp. 107-129, 2002.

[43] S.D. Shultz and D.A King, "The Use of Census Data for Hedonic Price Estimates of OpenSpace Amenities and Land Use," Journal of Real Estate Finance and Economics, vol. 22, pp. 239-252, 2001.

[44] C. Jim, Y. Wendy and Y. Chen, "Impacts of urban environmental elements on residential housing prices in Guangzhou (China)," Journal of landscape and urban planning, vol. 78, pp. 422-434, 2006.

[45] B. Bolitzer and N.R. Netusil, "The impact of open spaces on property values in Portland, Oregon," Journal of Environmental Management, vol. 59(3), pp. 185-193, 2000.

[46] S.T. Anderson and S.E. West, "Open space, residential property values and spatial context," Journal of Regional Science and urban economics, vol. 36(6), pp. 773-789, November 2006.

[47] Statistics South Africa, Victims of crime survey, Pretoria, South Africa, 2011.

[48] C. Loudier and J.L. Dubois, Public spaces: Between insecurity and hospitality, 2001.

[49] A. Shackell, Design for Play: A guide to creating successful play spaces, England, 2008.

[50] A.T. More, T. Stevens, and P.G. Allen, "Valuation of urban parks," Landscape and Urban Planning, vol. 15, pp. 139-152, 1988.
[51] J. Zomervrucht, Gradually grow to cycle: Experiences with a child-friendly public space, Netherlands, 2005.

[52] C.C. Marcus and C. Francis, People Places: Design Guidelines for Urban Open Spaces, 2nd ed. New York: Wiley, 1998.

[53] J. Byrne and N. Sipe, Green and Open Space Planning for Urban Consolidation - A Review of the Literature and Best Practice, Brisbane: Griffith University, 2010.

[54] TEEB, The Economics of Ecosystems \& Biodiversity: Ecosystem Services in Urban Management, 2011.

[55] L. Cilliers, Evaluating the spatial and environmental benefits of green space: An international and local comparison on rural areas, Dissertation submitted to the North-West University, Potchefstroom, 2014.

[56] H. Rohr, Water Sensitive Planning: An integrated approach towards sustainable urban water system planning in South Africa, Masters Dissertation submitted to the North-West University, Potchefstroom, 2012.

[57] O.H. Caspersen, C.C. Konijnendijk and A.S. Olafsson, "Green space planning and land use: An assessment of urban regional and green structure planning in Greater Copenhagen," Geografisk Tidsskrift, Danish Journal of Geography, vol. 106(2), pp. 7-20, 2006.

[58] C.J. Fausold and R. Lilieholm, "The economic value of open space: A review and synthesis", Environmental Management, vol. 23(3), 1999.

[59] M. Meadows, "The ecological resource base: biodiversity and conservation", the geography of South Africa in a changing world. Cape Town: Oxford University Press South Africa, 1999.

[60] S.J. Schmidt, "The evolving relationship between open space preservation and local planning practice", Journal of Planning History, vol. 7(2), pp. 91-112, 2008.

[61] C. Thompson, "Urban open space in the 21st century", Landscape and Urban Planning, vol. 2(7), pp. 59-72, 2002.

[62] H. Coetzee, Research Report 2: Needs assessment conducted in the Vaalharts Region, North West and Northern Cape Provinces, South Africa (A North West living labs baseline projects), Potchefstroom: Research Logistics cc, 2011. 